UNITED STATES DEPARTMENT OF THE INTERIOR

Harold L. Ickes, Secretary

GEOLOGICAL SURVEY

W. C. Mendenhall, Director

$$
18
$$

\title{
Bulletin 830
}

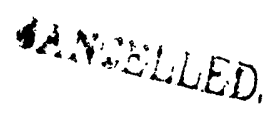

\section{CONTRIBUTIONS T0 ECONOMIC GEOLOGY}

(SHORT PAPERS AND PRELIMINARY REPORTS)

\section{1-32}

\section{PART I.-METALS AND NONMETALS EXCEPT FUELS}

\section{G. F. LOUGHLIN}

GEOLOGIST IN CHARGE

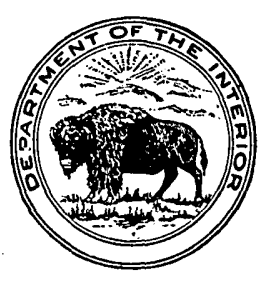

UNITED STATES

GOVERNMENT PRINTING OFFICA

WASHINGTON : 1933

For sale by the Superintendent of Documents, Washington, D. C. - - - - Price 30 cents 


\section{CONTENTS}

[The letters in parentheses preceding the titles are those used to designate the papers for advance publication]

(B) Geology of the Robertson, Humdinger, and Robert E. gold mines, southwestern Oregon, by P. J. Shenon

Notes on the Chieftain and Continental mines, Douglas County, Oreg., by F. G. Wells

\section{ILLUSTRATIONS}

PLATE 1. Areal geologic map of the Keating copper district, Oregon

2. Map of the workings of the Oregon Copper Co., on Balm Creek In pocket.

3. Map of the "Poorman" workings of the Oregon Copper Co., on Slide Creek In pocket.

4. Map showing geology in the vicinity of the Robertson mine, Josephine County, Oreg

5. Recrystallization in metagabbro of Robertson mine

6. Plan and section showing principal workings of Robertson mine

7. Photomicrographs of ore from Robertson mine

8. Plan and section of new workings of the Humdinger mine, Josephine County, Oreg.

9. Vein structure in specimens from Humdinger mine

10. Angular greenstone fragments from quartz vein in Humdinger mine

11. Plan of levels 3 and 4 of the Robert E. mine, Curry County, Oreg., with section through No. 1 raise

12. Photomicrographs of ores from Robert E. mine

13. Map of Chieftain mine, Douglas County, Oreg

14. Map of Continental mine, Douglas County, Oreg

Fiaure 1. Index map of northeastern Oregon, showing location of the Keating copper district.

2. Map of the Clover Creek Copper Co.'s prospect tunnel-_.-.-

3. Index map showing location of Robertson, Humdinger, and Robert E. mines, Josephine and Curry Counties, Oreg-.----

4. Township map showing Chieftain and Continental mines, Douglas County, Oreg 